\title{
Financial constraints and the interdependence of corporate financial decisions
}

A cross-country study

Guilherme Kirch

Universidade Federal do Rio Grande do Sul, Porto Alegre, Brazil, and

Paulo Renato Terra

Escola de Administração de Empresas de São Paulo da Fundação Getúlio Vargas (FGV-EAESP), São Paulo, Brazil
Financial constraints

Received 30 January 2019 Revised 12 April 2019 Accepted 16 April 2019

\begin{abstract}
Purpose - This paper aims to examine the interdependence of financial decisions (investment, financing, dividends and cash-holding) under financial constraints.

Design/methodology/approach - The authors specify and estimate a system of simultaneous equations with panel data and firm fixed effects by three-stage least squares in a sample of firms from 62 countries from 1996 to 2010.

Findings - The main findings largely corroborate previous studies regarding the interdependence of financial decisions. The authors also find evidence suggesting that financial constraints have a major impact on firms' financial decisions. The results also suggest that financial constraints manifest themselves in virtually all firms, indicating that such constraints are a matter of degree and not of kind.

Research limitations/implications - Implications regarding the impact of cash flows on investment and cash-holding decisions are only partially confirmed.

Practical implications - The results are consistent with the hypothesis that financial constraints distort the financial policies of firms. For the purpose of formulating policies that reduce these distortions, the authors emphasize the role of the availability of internal funds and the recoverable fraction of assets in easing financial constraints, thus allowing for greater investment on the part of firms.

Social implications - The results suggest that regulators should promote policies that reduce the dependence of corporate investment on internally generated cash flows.

Originality/value - Unlike previous studies, the authors account for the direct impact endogenous variables could have on each other. In addition, they explore the impact of each country's particular legal environment on the pledgeability of assets at the company level.
\end{abstract}

Keywords Financial constraints, Financial decisions, Cash flow sensitivity

Paper type Research paper

(c) Guilherme Kirch and Paulo Renato Terra. Published in RAUSP Management Journal. Published by Emerald Publishing Limited. This article is published under the Creative Commons Attribution (CC BY 4.0) licence. Anyone may reproduce, distribute, translate and create derivative works of this article (for both commercial and non-commercial purposes), subject to full attribution to the original publication and authors. The full terms of this licence may be seen at http://creativecommons.org/ licences/by/4.0/legalcode

Guilherme Kirch and Paulo Renato Terra contributed to all aspects of this article equally.

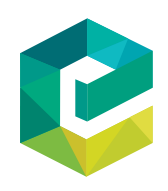

RAUSP Management Journal Vol. 55 No. 3,2020 pp. 339-354 
RAUSP

55,3

\section{Introduction}

In October 2018, the shares of the global brewing company Anheuser-Busch InBev had their most significant drop in a decade when it announced a 50 per cent cut in its dividends. Felipe Dutra, its chief financial officer, justified the sharp dividend reduction as necessary to pay down quickly its $\$ 108 \mathrm{bn}$ in debt from the acquisition of SABMiller in 2016 (Abboud, 2018). $\mathrm{AB}$ InBev is but one concrete example of how intertwined investment, financing and dividends decisions are in the corporate world. In this paper, we approach such a problem from a broad cross-country perspective. Our results help the understanding of the drivers of joint financial decisions and how financial constraints affect firms in different institutional environments.

In the credit market, informational asymmetries between individuals can cause credit rationing (Jaffee and Russell, 1976; Stiglitz \& Weiss, 1981). Moreover, problems of information asymmetry can raise the cost of external financing to the point where it becomes prohibitive for certain firms (Greenwald, Stiglitz, \& Weiss, 1984; Myers \& Majluf, 1984). Given these market imperfections, investment decisions could prove sensitive to the availability of internal funds and firm borrowing capacity. Besides, firms could also demand cash to alleviate the effects of financial constraints on future investments.

Among the most important recent theoretical developments in this stream of literature are the contributions of Acharya, Almeida, and Campello (2007) and Almeida and Campello (2007). Concerning the former, the main implication is that firms with higher asset pledgeability have greater access to credit, can make more investments and have higher sensitivity of investment to cash flows vis-à-vis firms with lower asset pledgeability. In the latter, Acharya et al. (2007) show that financially constrained firms with high hedging needs demand liquidity and thus the demand for cash should be sensitive to internally generated cash flows. These authors also show that the sensitivity of debt to cash flows is positive (negative) for firms with high (low) hedging needs.

Notwithstanding this, credit constraints imply that, contrary to the proposition put forward by Modigliani and Miller (1958), financial decisions are interdependent. Under credit rationing, investments in fixed assets, the maintenance of cash reserves, and dividend distributions are subject to the availability of internal and external funds. In other words, with the imposition of capital constraints, a firm's various forms of expenditure compete for limited funds, and thus financial decisions are determined simultaneously.

Although financial decisions could be determined simultaneously, investment, financing and liquidity demand models are generally estimated separately in the empirical literature. Some exceptions are the studies of Dhrymes and Kurz (1967), Fama (1974), McCabe (1979), McDonald, Jacquillat, and Nussenbaum (1975), Mueller (1967) and Peterson and Benesh (1983), among others. These studies are characterized by using systems of simultaneous equations to analyze the relations among firms' major financial decisions.

We empirically examine the implications of the models developed by Acharya et al. (2007) and Almeida and Campello (2007) in a context of simultaneity among firms' financial decisions in a sample of 62 countries. By taking the interdependence of financial decisions into account, we grasp a broader understanding of the decision-making process. As Mueller (1967, p. 58) states, "a complete understanding of this decision process can be obtained only by explicitly accounting for the numerous interactions which are a result of this simultaneity." Exploring this problem in a cross-country sample enables us to account for institutional differences that might give us a universal insight into the problem.

Our study contributes to the literature in several ways. First, we update the pioneering studies of Dhrymes and Kurz (1967), McCabe (1979), McDonald et al. (1975) and Peterson and Benesh (1983). Second, the system of simultaneous equations is estimated with panel 
data and firm fixed effects, as proposed by Cornwell, Schmidt, and Wyhowski (1992), rather than a series of cross-sectional estimations.

Chang, Dasgupta, Wong, and Yao (2014), Dasgupta, Noe, and Wang (2011) and Gatchev, Pulvino, and Tarhan (2010) also analyze firms' financial decisions by estimating a system of equations. In these studies, the system of equations only includes the explanatory variables considered to be predetermined and exogenous. Unlike the present study, those equations do not include the other endogenous variables among the explanatory variables, thus ignoring the direct impact these variables could have on financial decisions.

Other recent studies related to ours include Agliardi, Agliardi, and Spanjers (2016) which investigated the joint capital structure, dividend and liquidity demand decisions of firms using a behavioral approach. The authors model financial decisions under an ambiguity theory framework and find that ambiguity aversion has a first-order impact on those financial decisions. Exploratory empirical results from a cross-country sample provide initial support to the authors' model. Baños-Caballero, García-Teruel, and Martínez-Solano (2014) study the effect of financial constraints on working capital investment, and how their interplay affects financial performance in a sample of British companies. The authors find that for more financially constrained firms the optimal investment in working capital is lower than otherwise less constrained companies, which suggests severe impacts due to higher financing costs or greater capital rationing. Finally, Wang (2010) explores the interrelationship between investment, financing and dividend policies for high-tech firms in Taiwan and China. The author finds evidence that firms from that industry adopt different financial strategies subject to their own environments. None of these studies, however, has the same breadth and scope of ours in terms of countries, industries and financial decisions studied.

Finally, we explore the impact of the legal environment on firms' borrowing capacity to eliminate an alternative hypothesis associated with the results of Almeida and Campello (2007). These authors explore the variability in asset composition among firms as a source of variation in the pledgeability of firm assets. However, the composition of assets is partly determined by industry and, thus, the measure used by Almeida and Campello (2007) could be capturing other industry-related effects associated with corporate investment and not only variations in asset pledgeability. To explore the variability in asset pledgeability in more depth, we measure this variable conditional on each country's particular legal environment. We believe that the results of this strategy constitute original evidence that is complementary to Almeida and Campello's (2007) regarding a credit multiplier at the firm level.

We estimate the system of equations for a sample of 8,791 firms from 62 different countries[1] for the period from 1996 to 2010. The main results can be summarized as follows:

- The sensitivity of investment to cash flows is positive and increasing in the pledgeability of assets for both groups of firms, but the marginal effect of cash flows on investment is higher for firms classified as constrained.

- The sensitivity of cash to cash flows is positive and independent of hedging needs for firms classified as constrained and positive for firms classified as unconstrained with low hedging needs, but the marginal effect of cash flows on cash savings is higher for constrained firms.

- The sensitivity of debt to cash flows is negative for both groups of firms and independent of hedging needs, but the marginal effect of cash flows on debt issuance is higher (in absolute value) for firms classified as constrained. 
RAUSP

55,3

\section{2}

Our results suggest that the main financial decisions are interdependent and are sensitive to the availability of internal funds, supporting predictions about the effects of credit market frictions on the firm's financial policy. Specifically, our results are consistent with the following predictions:

- there is a credit multiplier effect at the firm level;

- firms save cash from cash flows to overcome future financial constraints; and

- firms prefer internal funds to external financing.

Our results also suggest that the effects of financial constraints are more severe for firms classified as constrained, corroborating the results of cross-countries studies by Becker and Sivadasan (2010), Francis, Hasan, Song, and Waisman (2013), Islam and Mozumdar (2007), Khurana, Martin, and Pereira (2006) and Kusnadi and Wei (2011).

Overall, we believe that our results convey a critical message: financial constraints manifest themselves virtually in all firms, possibly at different intensities, indicating that the restrictions are a matter of degree and not of kind. Finally, despite methodological differences, our results largely corroborate those of Dhrymes and Kurz (1967), McCabe (1979), McDonald et al. (1975), Mueller (1967), Peterson and Benesh (1983) and, more recently, Gatchev et al. (2010).

The remainder of this paper is organized as follows. In the next section, we develop our research hypotheses. In Section 3, we present the empirical model, the estimation procedure and the sample selection criteria. In Section 4, we discuss our main results. Finally, in Section 5 , we present our final comments and advice for regulatory bodies.

\section{Research hypotheses}

The hypotheses in this study stem from the empirical implications of models proposed by Acharya et al. (2007) and Almeida and Campello (2007) for the financial decisions of a firm. Regarding investment decisions, we formulate the following research hypothesis:

H1. Investment-cash flow sensitivity is positive and increasing in the recoverable fraction of assets for financially constrained firms and null for financially unconstrained firms.

According to Almeida and Campello (2007), if credit is rationed and the severity of the rationing is a decreasing function of the recoverable fraction of assets, firms with a higher fraction of recoverable assets have greater access to credit and can make more investments vis-à-vis firms with a smaller fraction of recoverable assets. As shown by Almeida and Campello (2007), given a positive shock to the availability of internal funds, the investments of constrained firms with a greater fraction of recoverable assets respond with greater intensity when compared to the investments of constrained firms with a smaller fraction of recoverable assets, due to higher endogenous variation in credit capacity of the former vis-àvis the latter. Almeida and Campello (2007) call this the credit multiplier effect.

Regarding the firm's demand for liquidity, we formulate the following hypothesis:

H2. The cash flow sensitivity of cash is positive (null) for constrained firms with high (low) hedging needs.

In the model of Almeida, Campello, and Weisbach (2004), the demand for liquidity arises as a means of ensuring that the firm is capable of investing in the future. However, as pointed out by Acharya et al. (2007), the choice of the appropriate instrument to transfer resources 
among states of nature depends on the firm's hedging needs. Constrained firms with high hedging needs (i.e. firms for which the correlation between investment opportunities and cash flows is low) choose to increase their cash holdings in periods of high cash flows as a means of transferring such funds to states of nature in which cash flows are low. Thus, the cash holdings of such firms should be positively sensitive to cash flows. For constrained firms with low hedging needs, increasing the borrowing capacity is a more efficient means of increasing the investment capacity in states of nature in which cash flows are high. Thus, such firms require no (additional) cash holdings for hedging purposes, and their cash flow sensitivity of cash should be null.

We formulate the following research hypothesis regarding the decision to issue new debt:

H3. The sensitivity of debt to cash flows is positive (negative) for constrained firms with high (low) hedging needs.

In the model of Acharya et al. (2007), constrained firms with high hedging needs use cash flows generated at times when investment opportunities are low as collateral for new loans and thus further increase their cash reserves. Therefore, such firms should have a positive cash flow sensitivity of debt. Constrained firms with low hedging needs, in turn, do not demand cash for hedging purposes and therefore use surplus cash flows to reduce debt and thereby increase their future borrowing capacity. Thus, such firms should have a negative cash flow sensitivity of debt.

As for financially unconstrained firms, Acharya et al. (2007) argue that, due to other possible benefits and/or costs associated with cash holdings and debt, cash and debt sensitivities to cash flows could differ from zero, but such sensitivities should be independent of the firm's hedging needs.

\section{Research method}

This section presents the empirical model used to test the research hypotheses, describes the estimation process and, finally, details the sample selection procedures and a priori classification of the firms as either financially constrained or unconstrained.

\subsection{Empirical model and estimation procedure}

As noted by Mueller (1967), a thorough understanding of a firm's decisions can only be achieved by explicitly recognizing the various interactions that result from the simultaneity among its decisions. With this purpose in mind, we estimate the following system of simultaneous equations for firm $i$ and period $t$ :

$$
\begin{aligned}
I_{i, t}= & \alpha_{0 i}+\alpha_{1} \Delta \operatorname{CaSh}_{i, t}+\alpha_{2} \operatorname{Div}_{i, t}+\alpha_{3} \Delta \text { Debt }_{i, t}+\alpha_{4} \Delta N W C_{i, t}+\alpha_{5} K_{i, t-1}+\alpha_{6} Q_{i, t-1} \\
& +\alpha_{7} C F_{i, t}+\alpha_{8} R F A_{i, t}+\alpha_{9}\left(C F_{i, t} \times R F A_{i, t}\right)+\mu_{t}+\varepsilon_{i, t}^{I} \\
\Delta \operatorname{Cash}_{i, t}= & \beta_{0 i}+\beta_{1} I_{i, t}+\beta_{2} \operatorname{Div}_{i, t}+\beta_{3} \Delta \operatorname{Debt}_{i, t}+\beta_{4} \Delta N W C_{i, t}+\beta_{5} \text { Cash }_{i, t-1}+\beta_{6} \text { Size }_{i, t} \\
& +\beta_{7} Q_{i, t}+\beta_{8} C F_{i, t}+\beta_{9}\left(C F_{i, t} \times H N_{i}\right)+\eta_{t}+\varepsilon_{i, t}^{\Delta \text { Cash }}
\end{aligned}
$$


RAUSP

55,3

$$
\begin{aligned}
\operatorname{Div}_{i, t}= & \gamma_{0 i}+\gamma_{1} I_{i, t}+\gamma_{2} \Delta \text { Cash }_{i, t}+\gamma_{3} \Delta \text { Debt }_{i, t}+\gamma_{4} \Delta N W C_{i, t}+\gamma_{5} \text { Div }_{i, t-1}+\gamma_{6} \text { Size }_{i, t} \\
& +\gamma_{7} Q_{i, t}+\gamma_{8} C F_{i, t}+\tau_{t}+\varepsilon_{i, t}^{D i v} \\
\Delta \text { Debt }_{i, t}= & \pi_{0 i}+\pi_{1} I_{i, t}+\pi_{2} \Delta \text { Cash }_{i, t}+\pi_{3} \text { Div }_{i, t}+\pi_{4} \Delta N W C_{i, t}+\pi_{5} \text { Debt }_{i, t-1}+\pi_{6} \text { Size }_{i, t} \\
& +\pi_{7} Q_{i, t}+\pi_{8} C F_{i, t}+\pi_{9}\left(\text { CF }_{i, t} \times H N_{i}\right)+\pi_{10} \text { RFA }_{i, t}+\pi_{10} \text { Risk }_{i, t}+\kappa_{t}+\varepsilon_{i, t}^{\Delta D e b t}
\end{aligned}
$$

This is not a structural system in which the equations derive directly from a firm's optimization problem. The system proposed herein intends merely to assess the relations among the endogenous variables and these variables' relations with their main determinants, which are derived from the financial literature, without inferring causality.

The endogenous variables of the system are an investment in physical capital $\left(I_{i, t}\right)$, changes in cash holdings $\left(\Delta \operatorname{Cash}_{i, t}\right)$, dividends $\left(\operatorname{Div}_{i, t}\right)$ and change in short- and long-term debt $\left(\Delta D e b t_{i, t}\right)$. The explanatory variables of the system are lagged capital stock $\left(K_{i, t-1}\right)$, lagged cash holdings $\left(\operatorname{Cash}_{i, t-1}\right)$, dividends paid the previous year $\left(\operatorname{Div}_{i, t-1}\right)$, the lagged stock of debt $\left(\right.$ Debt $\left._{i, t-1}\right)$, changes in net working capital $\left(\Delta N W C_{i, t}\right)$, current and lagged Tobin's $\mathrm{Q}$ $\left(Q_{i, t}, Q_{i, t-1}\right)$, firm size $\left(\right.$ Size $\left._{i, t}\right)$, cash flows generated over the period $\left(C F_{i, t}\right)$, the recoverable fraction of firm assets $\left(R F A_{i, t}\right)$, the interaction between these latter two variables, the interaction between the firm's cash flows and hedging needs $\left(H N_{i}\right)[2]$ and the firm's operational risk $\left(\operatorname{Ris}_{i, t-1}\right)$. A table with the expected signs of these variables is available upon request.

We applied the within transformation to the data to eliminate firm fixed effects, and we estimate the transformed system using the three-stage least squares method (3SLS). Cornwell et al. (1992) show that the maximum likelihood estimation of the original system is equivalent to that of the system after the within the transformation, thus justifying the estimation procedure adopted herein. We include dummy year variables to capture time effects.

\subsection{Sample, data collection and treatment}

The initial sample includes all firms in the manufacturing sector - Standard Industrial Classification (SIC) codes 2000-3999 - whose accounting and market information are available in the Compustat Global and Compustat North America databases for the period from 1996 to 2010[3]. All values are converted to US\$ and adjusted for inflation to constant 2010 dollars using the Consumer Pricing Index (CPI). The exchange rates are from the International Monetary Fund[4], and the Consumer Price Index is collected from the US Bureau of Labor Statistics. We drop from the sample those firms in which the following (firm-year) situations are observed:

- capital stock of less than US\$5m (December 2010 values);

- sales or asset growth greater than 100 per cent (lower limit bound at -100 per cent); and

- a Tobin's Q (current and lagged) that is negative or greater than 10.

In defining these exclusions, we follow the lead of Almeida and Campello (2007), who also use similar selection criteria. In addition, each firm must present at least two years of complete accounting and market information necessary to estimate the empirical models. 
The final sample consists of 60,488 observations (8,791 firms, unbalanced panel) from 62 countries.

Almeida and Campello (2007) explore the variability in the composition of assets among firms as a source of variation in the recoverable fraction of assets. However, we could argue that asset composition is determined partly by the firm's industry and thus the measure used by those authors could be capturing other industry effects associated with corporate investment and not only variations in the recoverable fraction of assets. We believe that by combining firm- and country-level variables, we can mitigate this alternative hypothesis, and we thus hope that our study contributes to a better understanding of the factors that affect the financial decisions of firms in a credit-constrained environment.

To explore the variability of the pledgeability of a firm's assets arising from the legal environment, we use a variable at the country level developed and computed by Djankov, Hart, McLiesh, and Shleifer (2008). Asset tangibility alone only measures the fraction of assets that can be offered as collateral and does not indicate how much of them can be recovered by creditors in the event of default (the true collateralizable value of the assets). Therefore, to determine the recoverable fraction of assets, the tangibility of firm assets is multiplied by the efficiency of debt enforcement at the country level. Debt enforcement is designed by Djankov et al. (2008) and measures the fraction of assets that can be recovered by creditors in the event of debt default. This measure is based on the procedures (most likely) used in each country to handle cases of corporate bankruptcy and accounts for costs, time, discount rate and so forth, of bankruptcy proceedings for a set of 88 countries.

Following Acharya et al. (2007), we classify firms concerning their hedging needs based on the correlation between a firm's cash flows and the industry's sales growth in the subsequent three years. We classify as having high hedging needs those firms whose correlation is statistically negative and for which the number of firms within the industry is greater than or equal to two in at least 75 per cent of the observations used to compute the correlation.

Firms are a priori classified between financially constrained and unconstrained according to the size of their total assets. Almeida et al. (2004), Almeida and Campello (2007), Dasgupta et al., (2011), Gilchrist and Himmelberg (1995), Kusnadi and Wei (2011), among others, also use size to ex-ante classify firms in these groups. For each country, industry (two-digit SIC code), and year, firms in the three lower (upper) deciles are classified as constrained (unconstrained). At least five firms with data for total assets in each country, industry and year are required[5]. For robustness, and guided by the evidence presented in Kaplan and Zingales (1997), we also report the results based on the financial slack criteria (we use our Cash variable as a measure of financial slack). In each country and year, we classify as constrained (unconstrained) those firms in the three lower (upper) deciles of our financial slack measure.

Finally, to mitigate problems arising from outliers, we adopt the following procedures:

- we truncate the asset tangibility variable above one (100 per cent); and

- we winsorize all other continuous variables at the firm level (except for firm size) at 1 per cent in both tails.

Table I presents the operationalization of each variable. These definitions follow the pertinent literature, except for the recoverable fraction of assets.

\section{Results}

We present the analysis of the results in two parts. The first includes the analysis of the descriptive statistics of the variables in the system of equations (1)-(4). In the second part, we 


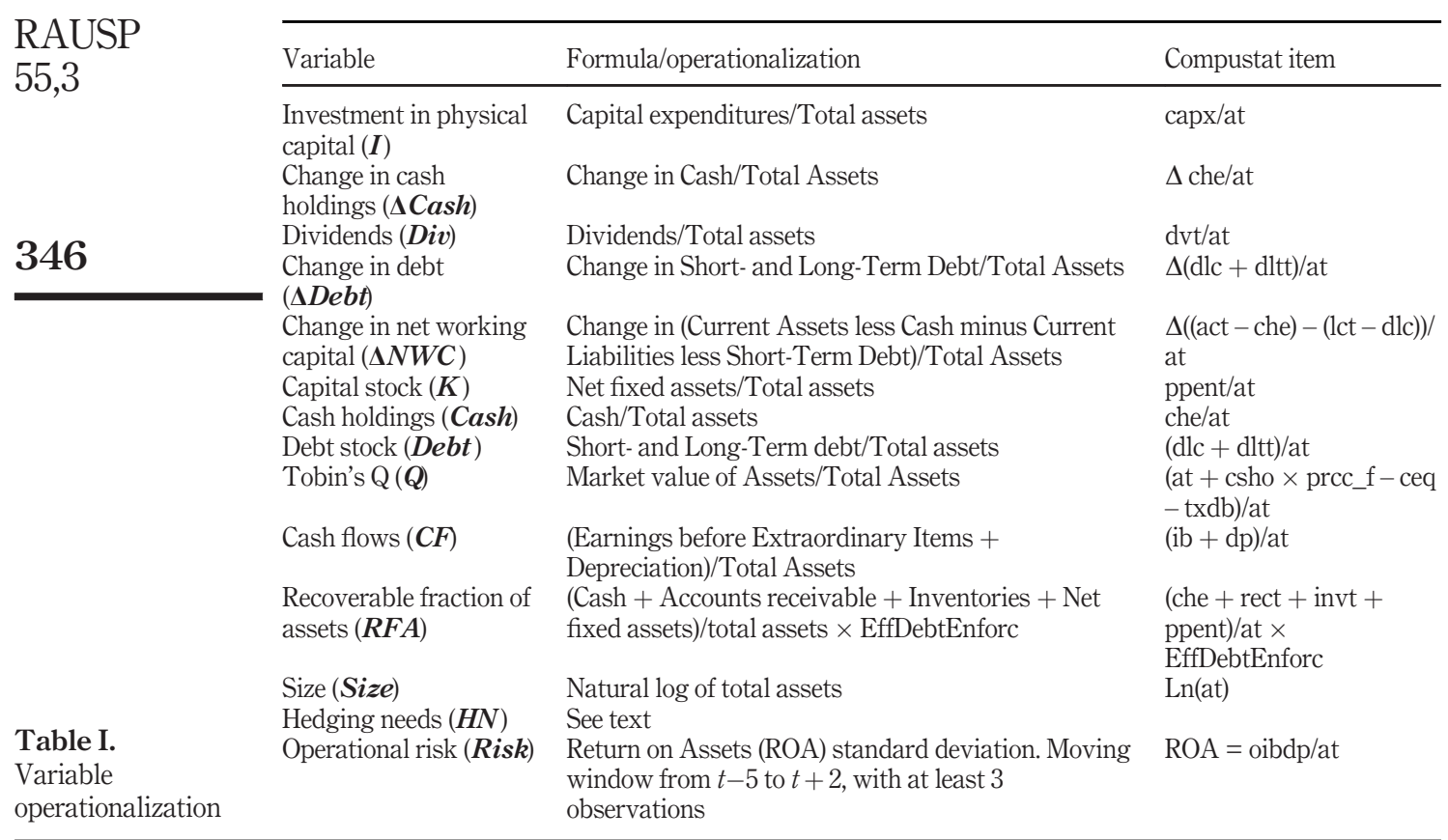

analyze and discuss the main results of the estimation of the system of equations. Several robustness tests were conducted, and the results remained the same (qualitatively). These additional tests are available upon request.

\subsection{Descriptive statistics}

Given the role of the efficiency of debt enforcement in this study, we highlight the relation of this variable with the asset tangibility variable. In countries such as Turkey, Brazil and Venezuela, where the average asset tangibility is higher than the overall mean, the recoverable fractions of such assets are, on average, only 5.7, 11.3 and 11.9 per cent, respectively. Therefore, even though the firms in these countries have, on average, greater levels of asset tangibility than their peers in other countries, the fraction of assets that could be recovered by creditors in a possible default of the firm is minimal.

These examples, though specific, are not exceptions, as can be noted in Figure 1, which presents a scatter plot of the efficiency of debt enforcement and average asset tangibility, together with a trend line. As can be seen, there is a negative linear relationship between these variables that is confirmed by the negative slope coefficient of the trend line (statistically significant at 1 per cent). This inverse relation suggests that, in studies involving firms from different countries, measuring the pledgeability of assets using tangibility alone could lead to serious measurement errors.

Table II presents the descriptive statistics calculated separately for the following subsamples[6]: firms classified as unconstrained, firms classified as constrained, and both types (total). From these statistics, we can ascertain the differences between the groups of firms regarding the main variables. By comparing the actual differences with those expected (based on theory), we can evaluate the effectiveness of our classification criteria. 


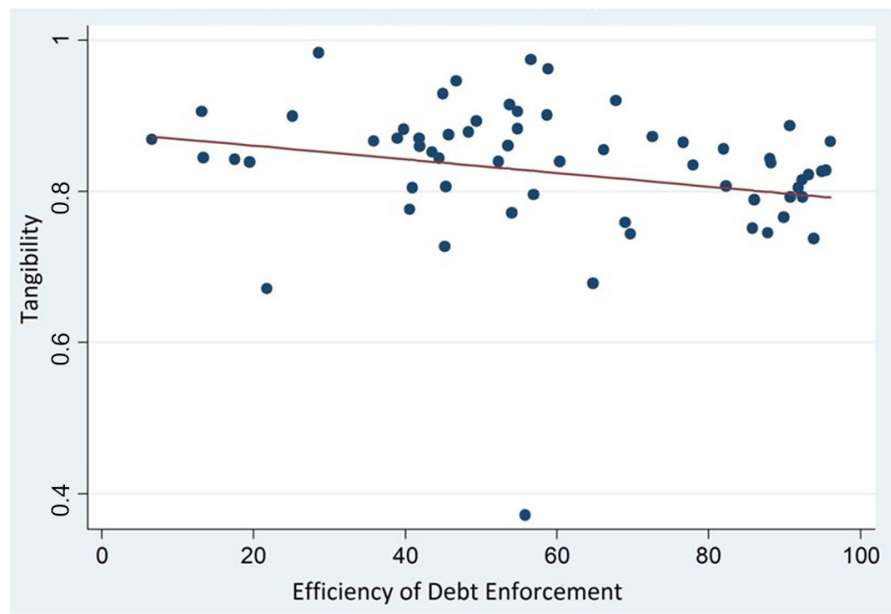

Financial constraints

According to the models of Acharya et al. (2007) and Almeida and Campello (2007), all being held constant, unconstrained firms tend to invest more, pay higher dividends and maintain lower cash holdings. Consistent with expectations, there are statistically significant differences between the two groups of firms in terms of the investment (I), dividend (Div) and cash holding (Cash) variables.

Almeida, Campello, and Weisbach (2011) show that financial constraints on future investments could distort the constrained firm's current investment policy. Such constraints lead firms to prefer investments with lower payback, less risk, greater liquidity and greater collateralizable value. The differences observed between the two groups of firms regarding investment in physical capital $(K)$ and the recoverable fraction of assets $(R F A)$ are consistent with this view.

Almeida et al. (2011) also argue that the potential impact of high debt on future financing costs can distort current investments, creating an additional cost of borrowing. Thus, constrained firms tend to use debt more conservatively vis-à-vis unconstrained firms. The differences observed between the groups of firms concerning debt stock (Debt) corroborate this prediction.

Regarding the remaining variables, there are also statistically significant differences between the two groups. These differences can generally be explained based on the theories, and empirical evidence discussed so far. Before concluding this analysis, we underline that the observed differences are consistent with the differences expected between firms with differential access to credit, suggesting that the adopted criterion is appropriate.

\subsection{Main results}

Table III shows the results for the estimations of the system (1)-(4) using the minimum chisquared generalized method of moments (GMM) estimator (GMM3SLS). We present our results in four columns, with two columns for each group, unconstrained and constrained firms. Columns I and II refer to the firm size and financial slack criteria, respectively.

Consider the results for the endogenous variables included among the explanatory ones for each equation and the variation in net working capital. Among these variables, four are representative of the use of funds - investment in fixed assets, demand for liquidity, dividends and changes in net working capital - and one is representative of the source of 
RAUSP

55,3

348
Table II.

Descriptive statistics of the variables in the system of equations (1)-(4)

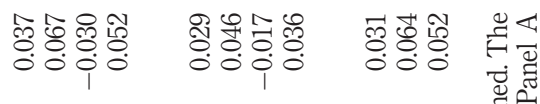

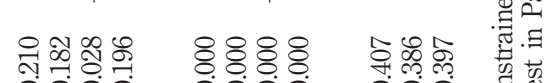

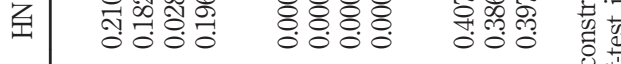

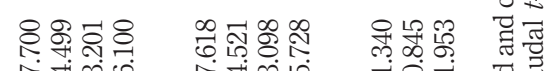

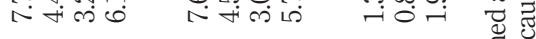

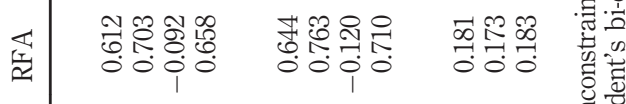

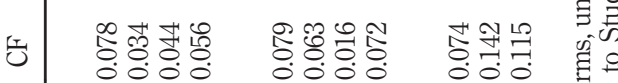

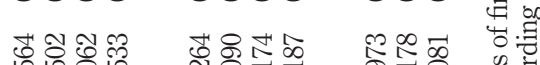

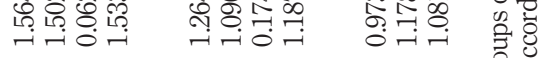

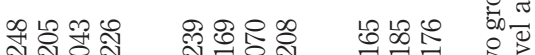

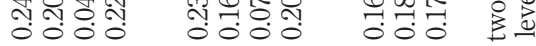

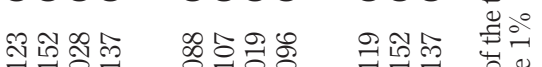

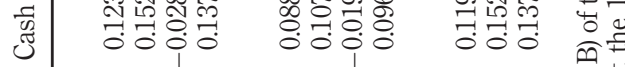

육데

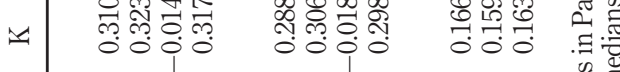

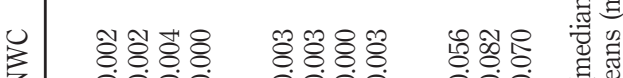

乡

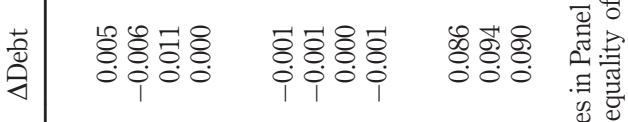

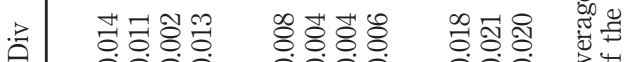

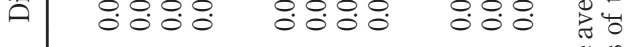

चี

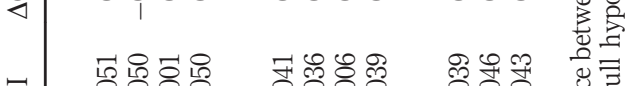

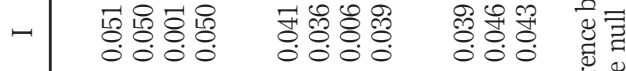

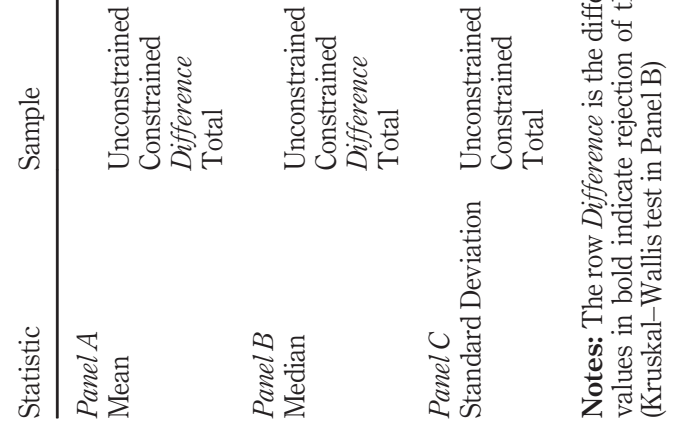




\begin{tabular}{|c|c|c|c|c|c|}
\hline \multirow[b]{2}{*}{ Explanatory variables } & \multicolumn{2}{|c|}{ Unconstrained } & \multicolumn{2}{|c|}{ Constrained } & \multirow{2}{*}{$\begin{array}{l}\text { Financial } \\
\text { constraints }\end{array}$} \\
\hline & I & II & I & II & \\
\hline \multicolumn{6}{|c|}{ Panel A: Investment equation $-I(t)$} \\
\hline$\Delta \operatorname{Cash}(\mathrm{t})$ & $0.0189 * * * *(2.61)$ & $0.0001(0.01)$ & $-0.0381 * * *(-4.42)$ & $-0.1593 * * *(-11.58)$ & \multirow{9}{*}{349} \\
\hline $\operatorname{Div}(\mathrm{t})$ & $0.0253(0.40)$ & $-0.1683^{* * *}(-2.82)$ & $-0.1397 *(-1.72)$ & $0.3260 * * *(3.01)$ & \\
\hline$\Delta$ Debt $(\mathrm{t})$ & $0.0867 * * *(11.74)$ & $0.0612^{* * *}(7.55)$ & $0.1411 * * *(16.31)$ & $0.1442 * * *(16.66)$ & \\
\hline$\Delta \mathrm{NWC}(\mathrm{t})$ & $-0.0309^{* * *}(-4.52)$ & $-0.0029(-0.56)$ & $-0.0632^{* * *}(-9.23)$ & $-0.1137 * * *(-14.42)$ & \\
\hline $\mathrm{Q}(t-1)$ & $0.0024 * * *(7.76)$ & $0.0028 * * *(11.17)$ & $0.0044 * * *(10.70)$ & $0.0058 * * *(7.84)$ & \\
\hline $\mathrm{CF}(\mathrm{t})$ & $-0.0076(-0.84)$ & $-0.0166 *(-1.73)$ & $0.0033(0.25)$ & $0.0162(1.36)$ & \\
\hline $\mathrm{RFA}(\mathrm{t})$ & $0.0731^{* * * * *(19.97)}$ & $0.1032 * * *(26.49)$ & $0.1242 * * *(21.36)$ & $0.0907 * * *(15.25)$ & \\
\hline $\mathrm{CF} \times \mathrm{RFA}(\mathrm{t})$ & $0.0725 * * *(5.24)$ & $0.0409 * * *(3.22)$ & $0.0641 * * *(3.63)$ & $0.0889 * * *(4.92)$ & \\
\hline Adj. $R$-squared & $14.3 \%$ & $11.0 \%$ & $17.5 \%$ & $19.1 \%$ & \\
\hline \multicolumn{6}{|c|}{ Panel B: liquidity demand equation $-\Delta$ Cash (t) } \\
\hline $\mathrm{I}(\mathrm{t})$ & $3.2772 * * *(13.81)$ & $3.7850 * * *(14.04)$ & $0.9198 * * *(7.21)$ & $0.1285^{* * * *}(4.04)$ & \\
\hline $\operatorname{Div}(t)$ & $-0.4359-(1.57)$ & $0.1756(0.59)$ & $0.3180(1.53)$ & $0.0227(0.38)$ & \\
\hline$\Delta$ Debt $(\mathrm{t})$ & $-0.2042 * * * *(-5.63)$ & $-0.0171(-0.36)$ & $0.0210(0.74)$ & $0.0022(0.32)$ & \\
\hline$\Delta \mathrm{NWC}(\mathrm{t})$ & $-0.1315 * * *(-4.72)$ & $-0.3284 * * *(-14.02)$ & $-0.2257 * * * *(-13.44)$ & $0.0077(1.40)$ & \\
\hline $\mathrm{CF}(\mathrm{t})$ & $0.0607 * * * *(2.76)$ & $0.2992^{* * * *}(14.55)$ & $0.2262 * * * *(16.57)$ & $0.0207 * * *(4.68)$ & \\
\hline $\mathrm{CF} \times \mathrm{HN}(\mathrm{t})$ & $-0.0503 *(-1.79)$ & $-0.0701^{* *}(-2.34)$ & $-0.0188(-0.78)$ & $0.0092(1.22)$ & \\
\hline Adj. $R$-squared & $-167.4 \%$ & $-83.3 \%$ & $12.1 \%$ & $74.2 \%$ & \\
\hline \multicolumn{6}{|c|}{ Panel C: dividend equation - Div ( $t)$} \\
\hline$I(t)$ & $0.1022^{* * * *}(4.41)$ & $0.0302(1.56)$ & $0.0611^{* * * *}(3.91)$ & $0.0530 * * *(3.36)$ & \\
\hline$\Delta$ Cash $(\mathrm{t})$ & $-0.0124 * * *(-4.29)$ & -0.0103 *** $(-5.02)$ & $-0.0083 * * *(-2.30)$ & $-0.0135 * * *(-3.01)$ & \\
\hline$\Delta$ Debt $(\mathrm{t})$ & $0.0040(1.14)$ & $0.0069 *(1.84)$ & $0.0025(0.59)$ & $0.0190 * * *(5.53)$ & \\
\hline$\Delta \mathrm{NWC}(\mathrm{t})$ & $-0.0142 * * *(-5.70)$ & $-0.0152 * * *(-6.35)$ & $-0.0095 * * *(-3.29)$ & $-0.0158 * * *(-5.47)$ & \\
\hline $\mathrm{CF}(\mathrm{t})$ & $0.0162^{* * * *}(8.14)$ & $0.0160 * * * *(9.87)$ & $0.0114^{* * * *}(5.07)$ & $0.0203^{* * *}(9.03)$ & \\
\hline Adj. $R$-squared & $11.8 \%$ & $10.6 \%$ & $8.3 \%$ & $7.3 \%$ & \\
\hline \multicolumn{6}{|c|}{ Panel D: debt equation $-\Delta$ Debt (t) } \\
\hline$I(t)$ & $0.9362 * * * *(4.84)$ & $-0.1464(-1.11)$ & $-0.1106(-0.86)$ & $0.0754(0.40)$ & \\
\hline$\Delta \operatorname{Cash}(\mathrm{t})$ & $0.1815 * * *(7.41)$ & $0.0940 * * *(7.62)$ & $0.2094 * * *(10.48)$ & $0.2753 * * *(6.44)$ & \\
\hline $\operatorname{Div}(t)$ & $1.2065 * * *(6.90)$ & $0.3433 * * *(2.58)$ & 0.2294 (1.17) & $1.6464 * * *(5.21)$ & Table III. \\
\hline$\triangle \mathrm{NWC}(\mathrm{t})$ & $0.5001 * * *(29.99)$ & $0.2458 * * *(19.49)$ & $0.4253 * * *(29.51)$ & $0.5924 * * *(36.73)$ & Results of the \\
\hline $\mathrm{CF}(\mathrm{t})$ & $-0.2587 * * * *(-13.82)$ & $-0.1523 * * *(-12.59)$ & $-0.2613 * * *(-18.39)$ & $-0.3322 * * * *(-17.60)$ & estimation of the \\
\hline $\mathrm{CF} \times \mathrm{HN}(\mathrm{t})$ & $-0.0439-(1.14)$ & $-0.0179(-0.77)$ & $0.0160(0.59)$ & $0.0085(0.25)$ & system of equations \\
\hline Adj. $R$-squared & $30.5 \%$ & $27.7 \%$ & $34.8 \%$ & $40.6 \%$ & by the minimum chi- \\
\hline \multirow{5}{*}{\multicolumn{5}{|c|}{$\begin{array}{l}\text { Notes: We only report the coefficients for the main variables (complete tables are available upon request). } \\
\text { The } t \text {-statistics are in brackets. The superscripts } * * *, * * \text { and * denote statistical significance at the } 1,5 \text { and } \\
10 \% \text { levels, respectively. Columns I and II refer to the firm size and financial slack criteria, respectively. See } \\
\text { Table I for details on the computation of the variables included in the regressions. In total, } 60,488 \\
\text { observations }(8,791 \text { firms, unbalanced panel) from } 62 \text { countries }\end{array}$}} & squared estimator \\
\hline & & & & & (GMM3SLS) after the \\
\hline & & & & & \\
\hline & & & & & lation of the \\
\hline & & & & & \\
\hline
\end{tabular}

funds - the issuance of new debt. For constrained firms, the prediction is that in the equations that represent the use of funds, the other variables representing this category will have negative coefficients, as such variables compete for scarce resources, while the variable representing the source of funds will have a positive coefficient, as the increased availability of external funds enables higher expenditures. The results generally confirm this expectation and just a few qualitative differences are observed between the classification criteria.

For unconstrained firms, the expectation is that, in the equations that represent the use of funds, neither the variables representing that category nor the variable representing the 
RAUSP

55,3

source of funds will have statistically significant coefficients. The results, however, do not confirm this expectation. In most cases, the sign of the coefficient of these variables is consistent with the expected behavior of financially constrained firms. For example, in the equation for investments in fixed assets, the issuance of new debt has a positive coefficient, indicating that increases in the availability of external funds relax the investment restrictions of such firms. Still, in the investment equation, the change in net working capital has a negative coefficient (firm size criterion), suggesting that these variables compete for scarce resources.

As for the equation for the issuance of new debt, the expectation is that the variables representing the use of funds have positive coefficients for both groups of firms, since increases in these variables require more funding, regardless of the firm's financial situation. Except for investments in fixed assets and dividends in the case of constrained firms, such expectations are confirmed. The exceptions could suggest that increases in investments and dividends are funded largely by other sources, mainly internal, given the high cost of external financing for this group.

Let's focus on our three research hypotheses. According to $H 1$, the sensitivity of investment to cash flows should be positive and increasing in the recoverable fraction of assets for constrained firms and zero for unconstrained firms. The sensitivity of investment to cash flows is computed for various values of the distribution of the recoverable fraction of the assets. These results are not reported but are available upon request.

The sensitivity of investment to cash flows is positive and statistically significant at the 1 per cent level for the constrained group. Moreover, the coefficients of the interaction between cash flows and the recoverable fraction of assets are positive and statistically significant at the 1 per cent level, suggesting that the sensitivity of investment to cash flows is increasing in the recoverable fraction of assets for this group of firms. All these results support $H 1$.

Qualitatively similar results are found for the unconstrained group. Except for the lower levels of the recoverable fraction of assets under the financial slack criteria, the sensitivity of investment to cash flows is positive and statistically significant (at the 5 per cent level at most) for this group of firms. The coefficients of the interaction between cash flows and the recoverable fraction of assets are positive and statistically significant at the 1 per cent level, suggesting that the sensitivity of investment to cash flows is increasing in the recoverable fraction of assets for the group of unconstrained firms. This evidence does not corroborate that presented by Almeida and Campello (2007) in a sample of US firms.

For unconstrained firms, the sensitivity of investment to cash flows is expected to be zero. The results, however, indicate that such firms behave similarly to firms classified as financially constrained. One explanation for this fact is that cash flow signals changes in the marginal productivity of capital that are not properly captured by the measures usually used for this purpose (Tobin's Q). However, based on the arguments presented by Almeida and Campello (2007), this alternative hypothesis could not explain the increasing sensitivity of investment to cash flows in the recoverable fraction of assets, unless the latter variable was also signalling changes in the marginal productivity of capital. Therefore, the most reasonable explanation seems to be that financial constraints are manifest in nearly all firms, possibly to different degrees. These results, therefore, suggest the rejection of $H 1$. Despite this, our results regarding the sensitivity of investment to cash flows corroborate those of Becker and Sivadasan (2010), Francis et al. (2013) and Islam and Mozumdar (2007), in cross-country settings.

Regarding the marginal effects of a one standard deviation change in cash flows on investment, there are differences between the two groups. Using the sensitivities calculated 
in the median of the recoverable fraction of assets under the firm size classification criterion, these effects are 0.0029 for unconstrained firms, that is, approximately 7 per cent of the median value of the investment in this group and 0.0074 for constrained firms, that is, approximately 21 per cent of the median value of the investment in this group. These figures, therefore, suggest that the investments of firms classified as constrained are twice as sensitive to a variation in the availability of internal funds when compared with firms classified as unconstrained.

In the demand for liquidity equation, we expect that only constrained firms with high hedging needs demand liquidity. The results, however, do not support this expectation and the findings of Acharya et al. (2007) and suggest that all firms classified as constrained require liquidity to ease restrictions on future investments.

For unconstrained firms, the expectation is that the cash flow sensitivity of cash will not be correlated with firm hedging needs. However, the coefficient of the interaction between cash flows and hedging needs is negative and statistically significant at the 10 per cent level (firm size) and the 5 per cent level (financial slack criterion), suggesting that the sensitivity of cash to cash flows varies with hedging needs. The results for both groups of firms thus suggest the rejection of H2. Again, our results are consistent with other cross-countries studies. Khurana et al. (2006) and Kusnadi and Wei (2011) also report evidence that the cash flow sensitivity of cash is positive for both groups of firms but higher for those classified as constrained.

Regarding the marginal effects on the demand for liquidity of a variation of one standard deviation in cash flows, there are substantial differences between the two groups of firms. Under the firm size classification criterion, this effect is 0.0321 for constrained firms, approximately 36 per cent of the standard deviation of the demand for liquidity in this group[7]. In the case of unconstrained firms, the marginal effect is 0.0045 for those with low hedging needs and 0.0008 for those with high hedging needs. These effects represent approximately 7 and 1.2 per cent, respectively, of the standard deviation of the demand for liquidity in this group of firms. Therefore, among firms classified as constrained, the demand for liquidity is more sensitive to variations in cash flows than among firms classified as unconstrained.

In the equation for the issuance of new debt, cash flows have a negative coefficient that is statistically significant at the 1 per cent level for both groups of firms. The interaction between cash flows and hedging needs has coefficients that are not statistically significant. These results indicate that, regardless of their financial situation and hedging needs, firms have a negative debt to cash flow sensitivity. For constrained firms, the prediction is that constrained firms with high hedging needs have a positive sensitivity of debt to cash flows. The results do not support this expectation and are in contrast to the findings presented by Acharya et al. (2007) and suggest that there is no difference in the sensitivity of debt to cash flows between constrained firms with high and low hedging needs. The results for both groups of firms, although broadly consistent with the previous evidence, suggest the rejection of $H 3$.

Regarding the marginal effects on the issuance of new debt of a one standard deviation change in cash flows, there is a substantial difference between the two groups. Under the firm size classification criterion, this effect is -0.0371 for constrained firms, approximately 40 per cent of the standard deviation of the issuance of new debt in this group. In the case of unconstrained firms, the marginal effect is -0.0191 , approximately 22 per cent of the standard deviation of the issuance of new debt in this group. These differences are in contrast to the results reported by Almeida and Campello (2010), who suggest that the 
RAUSP

55,3

relation between external financing and cash flows is more complementary in the case of financially constrained firms vis-à-vis unconstrained firms.

In short, our results suggest that financial constraints have a major impact on firms' financial decisions. Although we reject our hypotheses because the expected differences between the two groups of firms are not found, the implications regarding the impact of cash flows on firms' investment and cash decisions are partly confirmed. That is, the sensitivity of investment to cash flows is positive and increasing in the recoverable fraction of assets, and the cash flow sensitivity of cash is positive. The results therefore indicate that virtually all firms suffer from credit restrictions to some degree and are consistent with the previous cross-country studies of Becker and Sivadasan (2010), Francis et al. (2013), Islam and Mozumdar (2007), Khurana et al. (2006) and Kusnadi and Wei (2011).

\section{Concluding remarks}

This study aims to empirically investigate the implications of the models developed by Acharya et al. (2007) and Almeida and Campello (2007) in a context of simultaneity among firms' financial decisions. To eliminate the alternative hypothesis that the sensitivity of investment to cash flows varies by industry and not by firms' asset tangibility, we use a sample of international firms in conjunction with a country-level measure developed by Djankov et al. (2008). We believe that these advances provide original evidence regarding the credit multiplier at the firm level in a sample of firms from multiple countries.

To empirically investigate the implications proposed by Acharya et al. (2007) and Almeida and Campello (2007), we formulate three research hypotheses. The results suggest the rejection of the three hypotheses, as the expected differences between constrained and unconstrained firms are not confirmed.

Our results are consistent with the hypothesis that financial constraints distort the investment and financing policies of firms. To formulate policies that reduce these distortions, we emphasize the role of the availability of internal funds and the recoverable fraction of assets in easing financial constraints, thus allowing for greater investment on the part of firms. This result suggests that regulators should promote policies that reduce the dependence of corporate investment on internally generated cash flows.

Based on the literature and the findings of this study, regulatory bodies should promote:

- an environment with low-interest rates, as relatively high-interest rates amplify the effects of information problems in the credit market (Stiglitz \& Weiss, 1981);

- a financial intermediation structure that provides for the greater flow of information among agents, to reduce information problems in the credit market (Greenwald et al., 1984); and

- laws that allow creditors expeditious access to assets provided as collateral in lending operations, at low cost and with the best possible use of such assets (Djankov et al., 2008).

\section{Notes}

1. The list of countries included and the distribution of the observations in the final sample by country and year are available upon request.

2. For firms with higher hedging-needs, $H N_{i}=1$.

3. Cross-country studies based on accounting data are always subject to the criticism regarding comparability of the financial statements. To mitigate this problem, we rely on Compustat's 
thorough and comprehensive procedures for data standardization (Standard \& Poor's, 2002). We thank an anonymous referee for this remark.

4. For Taiwan, the exchange rates are collected from the National Statistics, Republic of China (Taiwan) website (http://eng.stat.gov.tw/mp.asp?mp=5).

5. The distribution of observations by industry and financial status is available upon request.

6. For conciseness, we report only the results for the firm size classification criterion. The results for the financial slack criterion are similar and available upon request.

7. In the case of demand for liquidity and new debt issuance, the standard deviation is used for purposes of comparison, as the mean and median for these variables are very close to zero.

\section{References}

Abboud, L. (2018). AB InBev shares drop on earnings miss and dividend cut. Financial Times. Retrieved from www.ft.com/content/9bdb2524-d818-11e8-a854-33d6f82e62f8

Acharya, V. V., Almeida, H., \& Campello, M. (2007). Is cash negative debt? A hedging perspective on corporate financial policies. Journal of Financial Intermediation, 16, 515-554.

Agliardi, E., Agliardi, R., \& Spanjers, W. (2016). Corporate financing decisions under ambiguity: Pecking order and liquidity policy implications. Journal of Business Research, 69, 6012-6020.

Almeida, H. \& Campello, M. (2007). Financial constraints, asset tangibility, and corporate investment. Review of Financial Studies, 20, 1429-1460.

Almeida, H. \& Campello, M. (2010). Financing frictions and the substitution between internal and external funds. Journal of Financial and Quantitative Analysis, 45, 589-622.

Almeida, H., Campello, M., \& Weisbach, M.S. (2004). The cash flow sensitivity of cash. The Journal of Finance, 59, 1777-1804.

Almeida, H., Campello, M., \& Weisbach, M. S. (2011). Corporate financial and investment policies when future financing is not frictionless. Journal of Corporate Finance, 17, 675-693.

Baños-Caballero, S., García-Teruel, P. J., \& Martínez-Solano, P. (2014). Working capital management, corporate performance, and financial constraints. Journal of Business Research, 67, 332-338.

Becker, B. \& Sivadasan, J. (2010). The effect of financial development on the investment-cash flow relationship: Cross-country evidence from Europe. Journal of Economic Analysis and Policy, 10, $1-49$.

Chang, X., Dasgupta, S., Wong, G., \& Yao, J. (2014). Cash-flow sensitivities and the allocation of internal cash flow. Review of Financial Studies, 27, 3628-3657.

Cornwell, C., Schmidt, P., \& Wyhowski, D. (1992). Simultaneous equations and panel data. Journal of Econometrics, 51, 151-181.

Dasgupta, S., Noe, T. H., \& Wang, Z. (2011). Where did all the dollars go? The effect of cash flows on capital and asset structure. Journal of Financial and Quantitative Analysis, 46, 1259-1294.

Dhrymes, P. J. \& Kurz, M. (1967). Investment, dividends, and external finance behavior of firms. In R., Ferber (Ed.), Determinants of Investment Behavior (pp. 427-485). New York, NY: NBER.

Djankov, S., Hart, O., McLiesh, C., \& Shleifer, A. (2008). Debt enforcement around the world. Journal of Political Economy, 116, 1105-1149.

Fama, E. F. (1974). The empirical relationships between the dividend and investment decisions of firms. American Economic Review, 64, 304-318. www.jstor.org/stable/1808884

Francis, B., Hasan, I., Song, L., \& Waisman, M. (2013). Corporate governance and investment-cash flow sensitivity: Evidence from emerging markets. Emerging Markets Review, 15, 57-71. 
RAUSP

55,3

Gatchev, V. A., Pulvino, T., \& Tarhan, V. (2010). The interdependent and intertemporal nature of financial decisions: An application to cash flow sensitivities. The Journal of Finance, 65, 725-763.

Gilchrist, S. \& Himmelberg, C. P. (1995). Evidence on the role of cash flow for investment. Journal of Monetary Economics, 36, 541-572.

Greenwald, B., Stiglitz, J. E., \& Weiss, A. (1984). Informational imperfections in the capital market and macroeconomic fluctuations. American Economic Review, 74, 194-199.

Islam, S. S. \& Mozumdar, A. (2007). Financial market development and the importance of internal cash: Evidence from international data. Journal of Banking and Finance, 31, 641-658.

Jaffee, D. M. \& Russell, T. (1976). Imperfect information, uncertainty, and credit rationing. Quarterly Journal of Economics, 90, 651-666.

Jensen, M. C. (1986). Agency costs of free cash flow, corporate finance, and takeovers. American Economic Review, 76, 323-329. www.jstor.org/stable/1818789

Kaplan, S. N. \& Zingales, L. (1997). Do investment-cash flow sensitivities provide useful measures of financing constraints? The Quarterly Journal of Economics, 112, 169-215.

Khurana, I. K., Martin, X., \& Pereira, R. (2006). Financial development and the cash flow sensitivity of cash. Journal of Financial and Quantitative Analysis, 41, 787-807.

Kusnadi, Y. \& Wei, K. C. J. (2011). The determinants of corporate cash management policies: Evidence from around the world. Journal of Corporate Finance, 17, 725-740.

McCabe, G. M. (1979). The empirical relationship between investment and financing: A new look. Journal of Financial and Quantitative Analysis, 14, 119-135.

McDonald, J. G., Jacquillat, B., \& Nussenbaum, M. (1975). Dividend, investment and financing decisions: Empirical evidence of French firms. Journal of Financial and Quantitative Analysis, 10, 741-755.

Modigliani, F. \& Miller, M. H. (1958). The cost of capital, corporation finance and the theory of investment. American Economic Review, 48, 261-297. www.jstor.org/stable/1809766

Mueller, D. C. (1967). The firm decision process: An econometric investigation. Quarterly Journal of Economics, 81, 58-87.

Myers, S. C. \& Majluf, N. S. (1984). Corporate financing and investment decision when firms have information the investors do not have. Journal of Financial Economics, 13, 187-221.

Peterson, P. P. \& Benesh, G. A. (1983). A reexamination of the empirical relationship between investment and financing decisions. Journal of Financial and Quantitative Analysis, 18, 439-453.

Stiglitz, J. E. \& Weiss, A. (1981). Credit rationing in markets with imperfect information. American Economic Review, 71, 393-410. www.jstor.org/stable/1802787

Wang, D. H.-M. (2010). Corporate investment, Financing, and dividend policies in the High-Tech industry. Journal of Business Research, 63, 486-489.

\section{Corresponding author}

Paulo Renato Terra can be contacted at: paulo.terra@fgv.br

Associate Editor: Luiz Paulo Fávero

For instructions on how to order reprints of this article, please visit our website:

www.emeraldgrouppublishing.com/licensing/reprints.htm

Or contact us for further details: permissions@emeraldinsight.com 